Pedagogical Research, 2:1 (2017), 01

ISSN: 2468-4929

\title{
Helping all Students Become Einstein's using Bibliotherapy when Teaching Mathematics to Prepare Students for a STEM World
}

\author{
Joseph M. Furner, Ph.D. ${ }^{1 *}$
}

${ }^{1}$ Florida Atlantic University, Jupiter, FL, USA

*Corresponding Author: jfurner@fau.edu

Citation: Furner, J.M. (2017) Helping all Students Become Einstein's using Bibliotherapy when Teaching Mathematics to Prepare Students for a STEM World. Pedagogical Research, 2(1), 01.

doi: $10.20897 /$ pedre.201701

Published: June 15, 2017

\begin{abstract}
Today, being confident and having a sound understanding of mathematics is critical in an age of STEM. Teachers must play in important role in seeing that all students display their confidence in their ability to do mathematics. This paper explains the process of using bibliotherapy when teaching mathematics to address both the math anxious or the math gifted student to build more math confidence in a STEM world. Often gifted students of mathematics can be made to feel bad by their peers just because they know mathematics and things come easy to them. Today there are many students in school that have math anxiety. Children's and adolescent literature has been recognized now as a means to teaching mathematics to students through the use of stories to make the mathematics concepts relevant and meaningful. Literature can also be used as a form of therapy, bibliotherapy, to reach students who may be frustrated with children picking on them for knowing a lot of mathematics or who are math anxious. Story and picture books such as Counting on Frank, Math Curse and $A$ Gebra Named $A l$ are now available to use in the classroom as forms of bibliotherapy in helping students come to terms with issues that haunt them as it relates to mathematics. Children's books can be beneficial to address the math anxious and even the gifted. In this paper the author proposes using reading and discussion (bibliotherapy) to help all students become confident in mathematics in the STEM world we live in.
\end{abstract}

Keywords: bibliotherapy, literature and picture books, mathematics confidence, STEM

\section{INTRODUCTION}

"Everybody is a genius. But ifyou judge a fish by its ability to climb a tree,

it will live its whole life believing that it is stupid."

\section{- Albert Einstein}

Buckminster Fuller once said, "Everyone is born a genius, but the process of living de-geniuses them." Today many young people in our schools who excel in the area of mathematics are often labelled or stigmatised by their peers as being nerds or a know-it-all. Educators must assure that all students develop confidence in their ability to do mathematics and gifted youngsters are no exception. Mathematical understanding is critical in an increasingly technological society. It is critical in our globally competitive world that most countries now produce more workers in the STEM (Science, Technology, Engineering, Mathematics) fields if they are going to be able to compete globally. Educators must make sure we nurture our strong mathematics, science, and technology students so that 
they pursue careers in these fields and not shy away from them due to being worried about being considered 'nerdy.' Often gifted students of mathematics are made to feel bad by their peers because they excel in mathematics and other academic disciplines come easy for them. Young people today are influenced by Hollywood stars, musicians, and professional sports players. 'Being a mathematician' is not always looked upon as being as glamorous or as exciting as being an NFL player. Within the past decade or two children's and adolescent literature has been recognized as a means to teaching mathematics concepts to students through the use of stories to make mathematics ideas relevant and meaningful. Children's literature can also be used as a form of therapy (bibliotherapy) to reach students who may be frustrated with being taunted or teased for excelling in mathematics. Story and picture books such as Counting on Frank (Clement, 1991), Math Curse (Scieszka \& Smith, 1995) and $A$ Gebra Named $A l$ (Isdell, 1993) are now available to use in the classroom as forms of bibliotherapy to help students come to terms with issues that haunt them just because either they are good at math or not so good. In this article the author proposes using reading and discussion (bibliotherapy) to aid in building math confidence in youngsters. Rozalski, Stewart, \& Miller (2010) based on their research have found that using carefully selected thematic books, teachers can use literature to reach young people who are experiencing difficult situations whether having math anxiety or feeling like geeks at math and worry about fitting in.

The following dialogue is an example of one parent's interaction with her son as it relates to why a gifted mathematic student may resort to avoiding showing their real knowledge of the subject matter because of peer pressure and the de-geniusing that occurs among our gifted and talented students:

While in the kitchen preparing dinner early one evening, my eleven year old son, Kevin came to me with some exciting news. 'Guess what Mom?! Guess what Mr. D said today?' 'What?' I replied enthusiastically. I knew Mr. D was Kevin's $6^{\text {th }}$ grade maths teacher who beld Kevin in high regard as a talented maths student.

'Mr. D said I should be in Algebra. He wants me to start working on Algebra.com.' That's because you are so smart in maths Kevin. I think that it is a wonderful idea.' 'Yeah, Mr. D says I am so smart in maths I should be in gifted, but my FCAT(Florida Comprehensive Assessment Test) score in $5^{\text {th }}$ grade was off by one point, so I can't. He makes me help all the other kids.' 'When you bave a talent or gift, you should always share that with others,'I said. 'Yeah, but they bug me too much. They're always asking me for the answers and to help them when they don't want to do the work, so now I just pretend I don't know how to do the problems even when I do.' I can't tell you the shock and dismay I felt when I heard those words - 'pretend I don't know' - come out the mouth of my child. I have always encouraged my sons to be proud of their talents; to recognise their limitations but give their best in whatever they do. Now I was hearing that my son was deliberately 'dumbing down' to adapt to an uncomfortable situation with his peers. It went against everything thing I thought I had taught them about self confidence, pride and acceptance of who they are. When the shock of his statement wore off and I had some time for thoughtful consideration, I realised that in as much as his bigh mathematical intellect is a gift that we celebrate, for my son, this 'gift' is also a burden. 'Dumbing down' is a coping mechanism that many gifted children use as a way to fit in socially with their peers. They don't want to be seen as different, even in the most positive regard.

Both teachers and parents interact with youngsters on a daily basis and see young people 'shut down' due to peer pressure or societal stigmas like being a 'nerd' just because mathematics comes easy for them. Dyer (2004) claims that many people are easily influenced by their peers and society pressures. As humans we allow others' influences to impact our egos and success in life. The idea of 'de-geniusing' hence, can happen to anyone, as in the case of Kevin above and with many gifted children around the world. It is a real phenomena that is happening to our youngsters in schools today who 'dumb down' in order to fit in with their peers and society as a whole. Renzulli $(2008,2011 \mathrm{a}, 2011 \mathrm{~b})$ has found that educators need to do more for the gifted to better reach them and foster an atmosphere where they can excel in academics without dumbing down the curriculum or short change some students who have great potential. This paper will provide a review of the literature as it relates to both the gifted mathematics student and use of bibliotheraphy and will make the argument for using bibliotherapy to help in the prevention of de-geniusing the mathematically gifted youngster. A sample lesson plan employing a children's literature picture book will be shared and how classroom teachers can work toward emphasising the importance of children being proud of their know-how of mathematics so not to dumb-down or minimise their true gifts and talents. Floyd \& Hebert (2010) contend that using picture book biographies can help to nurture the talents of youngsters. This paper shares how to use bibliotherapy to address the math anxious as well as the gifted to build math confidence in a STEM world.

\section{Both the math gifted and math anxious can benefit from children's literature}

Plucker (2008) and Johnsen (2004) synthesised cognitive characteristics that gifted students frequently exhibit particular to affective characteristics like having a sense of humor, being highly sensitive, taking other perspectives and are empathetic, and are often perfectionists. Schools need to provide professional development for teachers so that they can establish positive situations for gifts and talents to emerge as individuals who are proud of their talents and do not dumb-down their gifts due to societal and peer pressures. 
There is a myth that gifted children are better adjusted, more popular and happier than average children. The reality is that more frequently, the opposite is true (Renzulli, 2011b). For most gifted youngsters, childhood is more pleasurable because they derive joy from challenge and reward from work. At the same time, it is a childhood that is more painful, more isolated and more stressful because they do not fit in with their peers socially and they have high expectations for them selves as do others (Freedman and Jensen, n.d.) Also since gifted youngsters' intellectual capabilities are so strong, they have less need to develop their emotional intelligence. This underdeveloped emotional intelligence is a major pitfall in social interactions with peers. Parents and educators need to nurture and guide gifted children to becoming well balanced individuals and using bibliotherapy to address de-geniusing is one possibility. Van'Tassel-Baska \& Little (2011) also believe we need to foster such support for gifted students while also providing a strong emphasis on content-knowledge helping students to appreciate their gifts and excel in the subjects like mathematics.

Renzulli (2011a) and Diezmann and English (2001) believe that enrichment for mathematically gifted students in the elementary school needs to extend beyond puzzles or busywork and should support the development of mathematical power through a differentiated curriculum. Although mathematically gifted children are characterised by the quality of their reasoning abilities, these children require appropriate and challenging learning experiences to facilitate their cognitive development. Enrichment that consists of 'busy work' or irrelevant topics has limited academic value for gifted students. Although a student might be gifted, he or she still needs appropriate teacher support in dealing with challenging tasks that extend mathematical understanding as well as affective needs like being accepted by their peer in spite of their giftedness. . Enrichment programs play a key role in equipping these students with the foundational knowledge and skills to actively pursue their interests (Renzulli, 2011a; 2011b). Additionally, children's self-reflection of their learning can empower them in their work as mathematicians.

Diezmann (2000) contends that mathematical tasks that facilitate learning should be commensurate with the capability of the learner. For gifted students, this requires flexibility in the nature of task and appropriate support from others. Tasks of sufficient difficulty need to be carefully chosen or existing classroom tasks need to be adapted, that is, 'problematised.' Once the task is appropriately challenging, the teacher needs to provide support for the student. The need for support should be viewed positively, rather than negatively, because the more complex task provides an opportunity for mathematical learning that is not provided by an easier task. Furthermore, the teacher provides feedback to the student, highlights successful strategies, and acknowledges the student's capability. Gifted peers may also provide support and feedback in a positive way for young gifted students to be accepting of their true mathematical gifts where other peers may make fun of their mathematical knowledge.

Today it is important that schools and parents help to raise well-rounded young people who accept their gifts and/or math anxiety and come to terms with it so to gain confidence in mathematics to the STEM world we live in. Parents can impart valuable lessons to their gifted children while helping them achieve a balanced life. It is fine for gifted children to spend a lot of time pursuing their interests, but even the most advanced children should participate in family life, chores, playing with siblings and community involvement. A well-balanced life equals a well-rounded, happy young person.

Math anxiety is caused by a combination of external and internal factors; however, we cannot change internal factors within the student, so as teachers it makes more sense to focus on what we can control (Chernoff \& Stone, 2014). Studies show that math anxiety is caused primarily by the way the student learns math: the type of authority the teacher uses, an emphasis on right answers and fear of getting wrong answers, requirements that the student respond with an answer sooner than he or she might be ready, and exposure to the rest of the class and their potential condemnation of a student who responds poorly, in short the traditional way of teaching math (Chernoff \& Stone, 2014, Finlayson, 2014). Whether students are math anxious or gifted both groups can benefit from bibliotherapy. Appendix B provides a summary and process for addressing math anxiety and the use of bibliotherapy. Math anxiety is a well-documented phenomenon that has affected our society for over sixty years, and not enough is being done to address it in our classrooms or in the way we teach math (Dowker, Sarkar, \& Looi, 2016). Bibliotherapy can be an effective means to address the math anxious (See Appendix B).

Underachievement in exceptionally gifted students has been documented in the research. Fears of envy or retaliation and peer pressure can lead precocious intellects to resort to various forms of disengagement and withdrawal to avoid the emotional pain of such conflict (Grobman, 2006). Most students want to fit in, even the gifted, and they may mask their talents to do so. Hoover-Schultz (2005) contends that at first glance gifted underachievement seems like an oxymoron, it can also be an educational enigma. The loss to society can be tragic when students do not achieve to their full potential due to peer pressure or even it may be due to minor neurological problems that make underachievers behave this way. We must support all students, even the gifted so that they elevate themselves to their full potential. Cross (1997) brought this issue up repeatedly in her research about underachieving gifted students, students who know they are different, they know they show intelligence and are outspoken and then people tend to isolate them and put labels or expectations on the. Dumbing down can actually be thought of as a 'coping' strategy for these students in order to fit in (Cross, 1997; 2003). Cross believes that one 
of the most detrimental coping mechanisms academically gifted students employ is underachievement. According to Cross (1997) we must provide effective guidance to the gifted students to chart a new course for not lower their achievement just to fit in whether with peers, society, or competitive occurrences. Teachers need to teach their gifted students strategies so to not employ these severe patterns of coping behaviors that include trying to blend in with nongifted students, underachievement, and even suicidal behavior (Cross, 1997). Gifted programs certainly have many benefits. Even a study by Cross, Stewart, and Coleman (2003) showed that coparticipants in the study described feeling more accepted in the gifted magnet school than in previous non-magnet schools as they did not have to change who they were or dumb down their intellect to fit in. While it my not be possible for all gifted student to attend a gifted magnet school there are certainly benefits to this so that students do not have to become de-geniused. Plucker (2008) and Cross (2003) believes we must challenge many of the myths about the social and emotional developmental of gifted students and provide appropriate counseling and creating learning environments where students with gifts and talents can thrive. Below, the use of bibliotherapy as a form of counseling is suggested to reach these gifted students so they will not dumb-down to fit in with classmates and society.

Bain, Choate, and Bliss (2006) found in their empirical study that $77 \%$ of their total participants felt that gifted students are more likely to have problems with social relationships. This leads to them behaving in a way so to in better with all their peers at school. Young people who are gifted are often placed front-and-center in their school and community domains, as examples of the best individuals society can offer. Doing this adds erroneous pressure to these youngsters, which is often times unfair and leads to problems later on in life. Many gifted students are often de-genuised. We must help gifted students create plans that develop their talents to an optimal level. We must talk to them and work with them, they need to know though that using coping strategies to dumb-down their intelligence is really hurtful to them and ultimately our society if we as educators allow this.

\section{Using bibliotherapy in the math classroom}

Affective factors play such an important role in learning and teachers need practical classroom strategies to address the feelings of their students suffering from mathematics anxiety. Teachers need to create supportive environments in which their students feel comfortable expressing how they are feel about their mathematical experiences. One approach in helping young people express themselves comfortably is through bibliotherapy. Bibliotherapy is reading of selected literature to produce affective change and to promote personality growth and development (Betzalel \& Shechtman, 2010; Rozalski, Stewart, \& Miller, 2010; Watson \& Beswick, 2008; Jack \& Ronan, 2008; Furner and Kenney, 2011; Heath, Sheen, Leavy, Young, \& Money, 2005; Furner, 2004; Reis \& Renzulli, 2004; Sullivan \& Strang, 2003:Abdullah, 2002; Forgan, 2002 and 2003; Sridhar \& Vaughn, 2000; Doll and Doll, 1997; Jeon, 1992; Lenkowsky, 1987). Bibliotherapy can be used as an attempt to help young people understand themselves and cope with problems by providing literature relevant to their personal situations and developmental needs (Betzalel \& Shechtman, 2010). Hebert and Kent (2000) advocate the use of young adult literature for gifted teenagers to address social and emotional concerns. Classroom teachers using this approach hold a fundamental belief that reading will influence thinking and behavior, and that through guided discussions selected readings can be focused on specific needs of students.

The bibliotherapy process is fairly easy to understand and implement. The therapeutic experience while reading a book happens to us each time we pick up a good book and say, "This character is very much like me. I can relate to this person.' This interaction is known as identification, and the more we have in common with people we meet in our reading, the closer will be the identification process. That identification produces a sense of tension relief, or 'catharsis,' an emotional feeling that tells us we are not alone in facing our problems. As we enjoy the book, we learn vicariously through the characters in the book. We gain new ways of looking at troublesome issues we face and insight evolves. With this new insight, changed behavior may occur as real life situations similar to those experienced in the books are confronted. This may be the case with Kevin, presented in our case scenario earlier. When reading Counting on Frank, he may relate to the character and emulate his attitudes/methods for coping with his feelings as well as using the strategies presented for being proud of his mathematic prowess. The three most recognised stages of bibliotherapy are identifications, catharsis, and insight Jack \& Ronan,2008; Forgan, 2002; Halsted, 1994); however, another less mentioned in the literature yet especially interesting for teachers working with mathematics anxious students, is the concept of universalisation (Slavson, 1950), or the recognition that our problems are not unique. Through universalisation we realise that we, as sensitive individuals, 'are in this together.' Thatcher \& Fletcher (2008) have found that not all educators realize or see the value in using literature or bibliotherapy for address students' problems nor how to use such a process.

Books can help educators guide the emotional development of their students far more than intellectual discussion because stories directly affect human emotions (Rozalski, Stewart, \& Miller, 2010; Furner, 2004: Forgan, 2002; 2003). A skillful author can help young people connect with others who have similar problems. If books or short stories can touch young people emotionally, they may be much more receptive to ideas presented by the 
author than if they are presented to them in a lecture by a concerned teacher. Students who are unable to talk about their anxieties often can identify with characters in books strongly enough to experience the catharsis and acquire some important insights (Heath, Moulton,, Dyches, Prater, \& Brown, 2011; Halsted, 1994).

For bibliotherapy to be successful, a meaningful follow-up discussion is required (Furner, 2004; Forgan, 2002). To simply read a good book with an entire class is not bibliotherapy. It is very important that young people not only read books, but also become involved in discussions, counseling and follow-up techniques such as roleplaying, creative problem solving, and relaxation with music, art activities and journal writing (Furner and Kenney, 2011; Furner, 2004: Forgan, 2002 and 2003; Hebert, 1995, 1991; Hebert \& Furner, 1997). When presented in this way, bibliotherapy can be enjoyable while providing a time for solid introspection for young people.

It is important that sensitive school educators help students recognize that their abilities may differ from their peers, acknowledge that they may also have areas of weakness and assist them in developing self esteem by become satisfied with who they are as individuals (Ableser, 2008). Teachers using bibliotherapy may be successful in doing so by making connections to the students' attitudes and feelings with the characters in story books (Regan \& Page, 2008). Nugent (n.d.) contends that bibliotherapy should be considered a viable option for inclusion in the instructional methodology for gifted students to address affective/self-concept concerns. Leininger, Dyches, Prater, \& Heath, M. (2010), Burke (2009), and Kurtts \& Gavigan (2008) have all found that there are a wide range of literature and picture books useful in conducting bibliotherapy to address a wide range of conditions and societal factors impacting young people today.

Through this counseling approach, students come to understand that their avoidance or dumbing down was a learned behavior, they were not born with this feeling, and they can be taught to overcome it by consistently implementing their self-monitoring strategies to overcome the social stigmas that peers put on them about knowing mathematics. Since bibliotherapy is one avenue for students to discuss feelings about problems with others who share similar issues, the use of guided reading (Forgan, 2002) could naturally become one component of systematic desensitisation proposed by educational and psychological experts.

The book Counting on Frank by Rod Clement (1991), depicts the story of a middle school-aged boy's gift of mathematics. He goes through life knowing many things, counting, comparing, and knowing many number facts that all come easy to him. The book portrays him as somewhat of a nerd or geek. The book presents the reader with a variety of mathematics problems in a humorous yet realistic fashion as they relate to numbers, counting, and mathematics facts. The lesson plan (Appendix A) designed for teachers at the middle and high school levels, provides a variety of follow-up activities for use during or after reading Counting on Frank. These helpful activities are appropriate for infusing affective instruction into a mathematics curriculum over the course of a semester or even an entire academic year. The activities were designed with the realisation that teachers are often under pressure to teach many mathematical concepts and skills in an academic year. Forgan (2003) in his book entitled, Teaching Problem Solving through Children's Literature, offers many children's books to use in bibliotherapy sessions to help students overcome a variety of problems confronting young people today.

Integrating such activities like bibliotherapy and discussion while teaching math content consistently throughout a semester or an academic year would allow a teacher to address the feelings of their students as they learn mathematics. Such activities become an affective strand incorporated throughout their mathematics and language arts curricula. Teachers may consider working with the school counselor and use such an activity at least once a month or whenever they detect that their students are avoiding showing their true know-how of mathematics with their peers or experiencing some math anxiety. It is important for educators to do these recommended activities with their mathematical youngsters to help them gain the mathematics confidence preparing them to be ready for the STEM world we live in (See Sample Lesson in Appendix A and Math Anxiety Resources in Appendix B).

\section{Summary}

There are many students in schools around the world like Kevin or the boy in the book, Counting on Frank, who are made to feel like geeks or dumb-down their knowledge of mathematics in an effort to be accepted by their peers. 'De-geniusing' is a common phenomenon among gifted and talented students. Teachers need to take the time in their instruction to address the affective needs of these students since many may be made to feel like nerds just because they are good at mathematics or dumb for having math anxiety. This may also be relevant in other disciplines like the sciences and the technologies. To address this issue, teachers need to be trained in how to use bibliotherapy to assist students in accepting their giftedness in mathematics or math anxiety. Such strategies involve teachers taking time to discuss with their students how they are feeling about the subject they are learning. Reading children's or adolescent literature may be one approach mathematics teachers can use to reach students who may feel bad due to peers making fun of them because of their mathematically knowledge. Bibliotherapy is a therapeutic discussion-generating technique which offers caring educators appropriate affective strategies for dealing with preventing 'de-geniusing' of the mathematically gifted in classrooms so that students achieve success truly reflective 
of their true aptitude toward mathematics or to help them overcome their math anxiety and become more confident. It is important to note that as part of the NCTM (1989 and 2000) Standards teachers are responsible for assessing students' dispositions toward mathematics.

During the bibliotherapy session teachers should also do the mathematics with the students as it is discussed in the adolescent literature book. Bibliotherapy is not just a 'warm and fuzzy' approach. It is a serious form of psychological counseling and should be done to help students so to prevent this form of 'de-geniusing' or "anxiety" in mathematics or any other academic discipline. Bibliotheraphy then can serve as a way of being sensitive and non-intrusive way to help student solve problems and cope with issues in their personal life so that it will not affect their academic potential. Teachers need to take the time to discuss problems with students and employ techniques for student to share and discuss concerns which often are not brought out due to shame, fear, quilt, anxiety, or worries about fitting in. Kevin, like many of our young gifted youngsters today, dumb-down their true aptitude toward mathematics so that their peers do not make fun of them or use them to get the 'answers.' Many math anxious students are made to feel dumb and lack the confidence to do mathematics. All students should be proud and confident in mathematics and need to learn coping strategies for dealing with peer pressures that come with a discipline that is not as glamorous as a movie or rock star or a professional sports player. We need to help all young people be proud and confident of their mathematical abilities, so all have the opportunities to become like Einstein especially now in the STEM world we live in. Children's literature and bibliotherapy can promote this confidence our young people need.

\section{REFERENCES}

Abdullah, M. H. (2002). Bibliotherphy. ERIC Digest. Bloomington, IN: ERIC Clearinghouse. (ERIC Document Reproduction Service No. ED 470712).

Ableser, J. (2008). Authentic literacy experiences to teach and support young children during stressful times. Young Children, 63, 74-79.

Bain, S. K., Choate, S. M., \& Bliss, S. L. (2006). Perceptions of developmental, social, and emotional issues in giftedness: Are they realistic? Roeper Review, 29, 41-48.

Betzalel, N., \& Shechtman, Z. (2010). Bibliotherapy treatment for children with adjustment difficulties: A comparison of affective and cognitive bibliotherapy. Journal of Creativity in Mental Health, 5, 426-439.

Burke, A. (2009). Gifted and Grieving: Why It Is Critical to Offer Differential Support to Gifted Kids during Times of Loss. Gifted Child Today, 32, 30-37.

Chernoff, E., \& Stone, M. (2014). An Examination of Math Anxiety Research. OAME/AOEM

Gazette, 29-31.

Cross, T., Stewart, R. A, \& Coleman, L. J. (2003). Phenomenology and its implications for gifted studies research: Investigating the lebenwelt of academically gifted students attending an elementary magnet school. Journal for Education of the Gifted, 26, 201-220.

Cross, T. (2002). Competing with myths about the social and emotional development of gifted students. Gifted Child Today, 25, 44-45 and 65-66.

Cross, T. (1997). Psychological and social aspects of educating gifted students. Peabody Journal of Education, 72, $180-200$.

Diezmann, C. M., \& English, L. D. (2001). Developing young children's multidigit number sense. Roeper Review, 24, 11-13.

Diezmann, C. M. (2000). Catering for mathematically gifted elementary students: Learning from challenging tasks. Gifted Child Today, 23, 14-20.

Doll, B., \& Doll, C. (1997). Bibliotherapy with young people: Librarians and mental health professionals working together. Englewood, CO: Libraries Unlimited.

Dowker, A., Sarkar, A., \& Looi, C. Y. (2016). Mathematics Anxiety: What Have We Learned in

60 Years? Frontiers in Psychology, 7, 508. http://doi.org/10.3389/fpsyg.2016.00508

Dyer, W. W. (2004). The power of intention: Learning to co-create your world your way. Carlsbad, CA: Hay House, Inc.

Finlayson, M. (2014). Addressing math anxiety in the classroom. Improving Schools, 17(1), 99-

115. doi: $10.1177 / 1365480214521457$

Floyd, E. F. \& Hebert, T. P. (2010). Using Picture Book Biographies to Nurture the Talents of Young Gifted African American Students. Gifted Child Today, 33, 38-46.

Forgan, J. W. (2002). Using bibliotherapy to teach problem solving. Intervention in School and Clinic, 38, 75-82.

Forgan, J. W. (2003). Teaching problem solving through children's literature. Westport, Connecticut: Teacher Ideas Press Libraries Unlimited 
Forschmiedt, J., (n.d.). Striking a balance: How to raise a well-rounded gifted child. Retrieved October 19, 2005, from http://www.newhorizons.org/spneeds/gifted/forschmiedt.htm.

Freedman, J., \& Jensen, A. (n.d.). Joy and loss: The emotional lives of gifted children. Retrieved October 19, 2005, from http://www.kidsource.com.

Furner, J. M. (2004). Using bibliotherapy to overcome math anxiety. Academic Exchange Quarterly, 8, $209-213$.

Furner, J.M., \& Kenney, C. (2011). Counting on Frank: Using bibliotherapy in mathematics teaching to prevent de-geniusing. Pythagoras, 32(2), Art. \#133, 7 pages. http://dx.doi.org/10.4102/pythagoras.v32i2.133.

Grobman, J. (2006.) Underachievement in exceptionally gifted adolescents and young adults: A psychiatrist's view. The Journal of Secondary Gifted Education, 4, 199-210.

Halsted, J. W. (1994). Some of my best friends are books: Guiding gifted readers from pre-school to high schools. Dayton, OH: Ohio Psychology Press.

Heath, M. A., Moulton, E., Dyches, T. T., Prater, M. A. \& Brown, A. (2011). Strengthening elementary school bully prevention with bibliotherapy. Communique, 39, 12-14.

Heath, M. A., Sheen, D., Leavy, D., Young, E., \& Money, K. (2005). Bibliotherapy: A resource to facilitate emotional healing and growth. School Psychology International, 26, 563-580.

Hebert, T. P., \& Kent, R. (2000). Nurturing social and emotional development in gifted teenagers through young adult literature. Roeper Review, 22, 167-171.

Hebert, T. P. \& Furner, J. M. (1997). Helping high ability students overcome math anxiety through bibliotherapy. The Journal of Secondary Gifted Education, 4, 164-178.

Hebert, T. P. (1995). Using biography to counsel gifted young men. The Journal of Secondary Gifted Education, 6, 208-219.

Hebert, T. P. (1991). Meeting the affective needs of bright boys through bibliotherapy. Roeper Review, 13, $207-$ 212.

Hoover-Schultz, B. (2005). Gifted underachievement: oxymoron or educational enigma? Gifted Child Today, 28, 46-49.

Isdell, W. (1993). A Gebra named Al. Minneapolis, MN: Free Spirit Publishing Inc.

Jack, S. J., \& Ronan, K. R. (2008). Bibliotherapy: Practice and research. School Psychology International, 29, 161182.

Jeon, K., (1992). Bibliotherapy for gifted children. Gifted Child Today, 15, 16-19.

Johnsen, S. K. (2004). Identifying gifted students: a practical guide. Waco, Texas: Prufrock Press, Inc.

Kurtts, S. A., \& Gavigan, K. W. (2008). Understanding (dis)abilities through children's literature. Education Libraries, 31, 23-31.

Leininger, M., Dyches, T. T., Prater, M. A., \& Heath, M. A. (2010). Newbery award winning books 1975-2009: How do they portray disabilities? Education and Training in Autism and Developmental Disabilities, 45, 583596.

Lenkowsky, R. S. (1987). Bibliotherapy: A review and analysis of the literature. The Journal of Special Education, 21, 123-132.

Murphy, F., \& Walz, R. (2001). Ben Franklin and the Magic Squares. New York, NY: Random House Books for Young Readers.

National Council of Teachers of Mathematics. (2000). Principles and Standards for School Mathematics. NCTM: Reston, VA.

National Council of Teachers of Mathematics. (1989). Curriculum and evaluation standards for school mathematics. Reston, VA: Author.

Nugent, S. (n.d.) Bibliotherapy: A study of its effects on the self-concept of gifted students. Retrieved October 19, 2005, from http://www.selu.edu/Academics/Education/EDF600/steph.htm.

Plucker, J. (2008). Critical issues and practices in gifted education: What the research says. Waco, TX: Prufrock Press Inc.

Regan, K., \& Page, P. (2008). "Character" building: Using literature to connect with youth. Reclaiming Children and Youth: The Journal of Strength-based Interventions, 16, 37-43.

Reis, S. M., \& Renzulli, J. S. (2004). Current research on the social and emotional development of gifted and talented students: Good news and future possibilities. Psychology in the Schools, 41, 119-130.

Renzulli, J. S. (2008). Teach to the top: How to keep high achievers engaged and motivated, Instructor, $117,34$.

Renzulli, J. S. (2011a). Theories, actions, and change: An academic journey in search of finding and developing high potential in young people, Gifted Child Quarterly, 55, 305-308.

Renzulli, J. S. (2011b). Kappan classic: More changes needed to expand gifted identification and support. Phi Delta Kappan, 92, 61.

Rozalski, M., Stewart, A., \& Miller, J. (2010). Bibliotherapy: Helping children cope with life's challenges. Kappa Delta Pi Record, 47, 33-37. 
Scieszka, J., \& Smith, L. (1995). Math Curse. NY, NY: Viking Press.

Slavson, S. R. (1950). Analytic group psychotherapy with children, adolescents, and adults. New York: Columbia University Press.

Sullivan, A.K., \& Strang, H. R. (2003). Bibliotherpy in the classroom: Using literature to promote the development of emotional intelligence. Childhood Education, 79, 74-80.

Sridhar, D., \& Vaughn, S. (2000). Bibliotherapy for all: Enhancing reading comprehension, self-concept, and behavior. Teaching Exceptional Children, 33, 74-82.

Thatcher, K., \& Fletcher, K. (2008). Professionals' perceptions of the role of literacy in early intervention services. Psychology in the Schools, 45(7), 600-608.

VanTassel-Baska, J., \& Little, C. A. (2011). Content-Based curriculum for high-Ability learners, 2nd. Edition, Waco, TX: Prufrock Press Inc.

Watson, J. \& Beswick, K. (2008). Mathematics: Essential Research, Essential Practice. Volumes 1 and 2. Proceedings of the 30th Annual Conference of the Mathematics Education Research Group of Australasia, Mathematics Education Research Group of Australasia. 


\section{Appendix A: A Sample Bibliotherapy Lesson Plan featuring Counting on Frank}

Counting on Frank by Rod Clement (1991), depicts the story of a middle school-aged boy's gift of mathematics. He goes through life knowing many things, counting, comparing, and knowing many number facts that all come easy to him. The book portrays him as somewhat of a nerd or geek. The book presents the reader with a variety of math problems in a humorous yet realistic fashion as they relate to numbers, counting, and math facts. The following lesson plan is designed for teachers at the middle and high school levels, provides a variety of follow-up activities for use during or after reading Counting on Frank. These helpful activities are appropriate for infusing affective instruction into a math curriculum over the course of a semester or even an entire academic year. The activities were designed with the realisation that teachers are often under pressure to teach many mathematical concepts and skills in an academic year. Forgan (2003) in his book entitled, Teaching Problem Solving through Children's Literature, offers many children's books to use in bibliotherapy sessions to help students overcome a variety of problems confronting young people today.

Integrating such activities like bibliotherapy and discussion while teaching the content consistently throughout a semester or an academic year would allow a teacher to address the feelings of their students as they learn mathematics. Such activities become an affective strand incorporated throughout their math and language arts curricula. Teachers may consider working with the school counselor and use such an activity at least once a month or whenever they detect that their gifted students are avoiding showing their true know-how of mathematics with their peers. It is important for educators to do these recommended activities with their mathematically gifted youngsters to help them gain the math confidence and to prevent de-geniusing.

$\underline{\text { Book }}$

Clement, R. (1991). Counting on frank. Milwaukee, WI: Gareth Stevens Publishing.

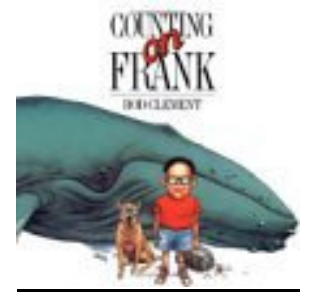

Annotation

A boy and his dog present amusing counting, size comparison, and mathematical facts from a unique perspective of their world. The main character, a young man whose name is never mentioned, always knows the answers and is full of facts. The book offers a serious of questions at the end of the book called, 'Here's a Chance to Use YOUR Brain!' which many young gifted students may enjoy investigating.

Menu of Themes/Key Concepts:

- Everyone has a unique way of looking at the world.

- Mathematically gifted should not be embarrassed because they are good at math

- Math is used in everyday life events.

- Gifted and talented students are embarrassed by their math abilities and tend to diminish their skills/talents.

- Mathematics can be easy, fun and rewarding.

- There are many misconceptions about mathematics.

Discussion questions:

- Some people say that math is used in everyday life. Can you give me some examples?

- How do you feel when adults say math surrounds us?

- Do you think people learn math in different ways? Why? How?

- How do you learn math best?

- How do you feel when an adult tells you to use your brain? Why?

- What do you think is the most frightening thing about math? What is the best thing about math?

- Describe how math teachers help you to use your brain. How can you do this on your own?

- Do you share your feelings about math with other people?

- Most people think that the ability to do math in a necessary life skill. How does that belief make you feel about your math ability? Do you agree/disagree?

- Should all smart students be expected to love math? Why or why not?

- What advice would you give to younger students about learning and enjoying mathematics?

- What are some ways you be proud of your math skills?

Menu of Possible Activities: 
- The book concludes with four pages of math problems directly related to the story that give students a chance to use math and numbers in fun ways. The teacher can allow the students to explore and solve these problems.

- Students can write their own word problems relating to everyday life events for classmates to solve.

- Students can write a reflective essay about the importance of math in everyday life and how this affects their own beliefs about their math skills and abilities.

- Have students write a poem about their math ability and allow time to share with the class.

- Have students create a picture collage of examples of math use in everyday life.

- Have students keep a math journal to record their feelings about mathematics and share times when others made them feel like a nerd or bad for being good at math.

- Have students create a 'counting' math song and allow to perform in front of classmates.

- Group students into teams to play Math Jeopardy. Students have to work collaboratively to solve word problems.

- Invite professional community members to come in to discuss how they use math in their business.

- Allow students to investigate mathematicians through time and identify some who may have been gifted and have them report back their contributions to mathematics.

- Student may want to review the book and notice the character and how he is dressed and portrayed, does the book portray him as a 'nerd?' How would you change this portrayal?

- Another book mathematically gifted youngsters may enjoy is:

- Murphy, F., \& Walz, R. (2001). Ben Franklin and the Magic Squares. New York, NY: Random House Books for Young Readers.

- This book shares the life of Ben Franklin and his work and contribution to mathematics, particularly, Magic Squares. Gifted students may enjoy playing and learning about different magic squares.

Interactive Mathematics Websites that may be used and appeal to the Mathematically Gifted:

www.Funbrain.com

www.Coolmath4kids.com

www.Math.com

www.Brainpop.com

Use www.globalclassroom.org for links to a multitude of interactive math websites. 


\section{Appendix B: Tips for Addressing Math Anxiety}

Mathematics teachers need to be counselors too..........

What NCTM says about Mathematics Anxiety and Dispositions Toward Mathematics

\section{Standard 10: Mathematical Disposition (NCTM 1989)}

As mathematics teachers it is our job to assess students' mathematical disposition regarding: -confidence in using math to solve problems, communicate ideas, and reason;

-flexibility in exploring mathematical idea and trying a variety of methods when solving;

-willingness to persevere in mathematical tasks;

-interests, curiosity, and inventiveness in doing math;

-ability to reflect and monitor their own thinking and performance while doing math;

-value and appreciate math for its real-life application, connections to other disciplines and cultures and as a tool and language.

\section{A Synthesis on How to Reduce Math Anxiety}

1. Psychological Techniques like anxiety management, desensitization, counseling, support groups, bibliotherapy, and classroom discussions.

2. Once a student feels less fearful about math he/she may build their confidence by taking more mathematics classes.

3. Most research shows that until a person with math anxiety has confronted this anxiety by some form of discussion/counseling no "best practices" in math will help to overcome this fear.

\section{A Synthesis on How to Prevent Math Anxiety}

1. Using "Best Practice" in mathematics such as: manipulatives, cooperative groups, discussion of math, questioning and making conjectures, justification of thinking, writing about math, and problem-solving approach to instruction, content integration, technology, and assessment as an integral part of instruction, etc.

2. Incorporating the NCTM Standards and your State Standards into curriculum and instruction.

3. Discussing feelings, attitudes, and appreciation for mathematics with students regularly 